\title{
LEAVES EXTRACT-BASED BIOGENIC SYNTHESIS OF CUPRIC OXIDE NANOPARTICLES, CHARACTERIZATIONS, AND ANTIMICROBIAL ACTIVITY
}

\author{
NAVEEN CHANDRA JOSHI ${ }^{1 *}$, YASHWANI PRAKASH ${ }^{2}$ \\ ${ }^{1}$ Department of Chemistry, Uttaranchal University, Dehradun, Uttarakhand, India. ${ }^{2}$ Department of Chemistry, Uttaranchal University, \\ Dehradun, Uttarakhand, India. Email: drnaveen06joshi@gmail.com
}

Received: 19 May 2019, Revised and Accepted: 19 June 2019

\section{ABSTRACT}

Objectives: Tulsi (Ocimum tenuiflorum) leaves extract-based synthesis of cupric oxide nanoparticles (CuONPs), characterizations, and antimicrobial activity.

Methods: The small cut leaves were washed with double distilled water and boiled for 30 min. After filtration, the extract was treated with $0.2 \mathrm{M}$ copper acetate solution and the initial color change of this solution indicated formation of copper nanoparticles. This solution was stirred for a specific time, heated and treated with $0.1 \mathrm{M} \mathrm{NaOH}$ solution. The formation of CuONPs was confirmed by the development of brownish-black precipitates. Then, CuONPs have been tested for their antibacterial effects by applying well diffusion method against Escherichia coli, Streptococcus mutans, Proteus vulgaris, and Staphylococcus aureus.

Results: The biologically synthesized CuONPs have been well characterized by using ultraviolet-visible, Fourier-transform infrared, X-ray powder diffraction, and field-emission scanning electron microscopy techniques and all these analytical methods indicated a successful and efficient formation of CuONPs. After the incubation period, significant zones of inhibition were observed for E. coli, S. mutans, P. vulgaris, and S. aureus.

Conclusions: The method was found highly efficient, eco-friendly, and low cost for the synthesis of biologically important CuONPs. The CuONPs have been found an excellent antibacterial agent.

Keywords: Cupric oxide nanoparticles, Ocimum tenuiflorum, Biological synthesis, Characterizations, Antimicrobial activity

(C) 2019 The Authors. Published by Innovare Academic Sciences Pvt Ltd. This is an open access article under the CC BY license (http://creativecommons. org/licenses/by/4. 0/) DOI: http://dx.doi.org/10.22159/ajpcr.2019.v12i8.34182

\section{INTRODUCTION}

The major advantages of nanotechnology in chemical, biological, and engineering sciences are to improve the efficiency, durability, and effectiveness of the materials. The physical, chemical, and biological properties of nanomaterials are usually differ and improved due to the change in the ratio of surface area to volume [1]. The conventional methods used to synthesize nanoparticles are not much efficient, needed harmful chemicals, and unsafe to the environment. The applicability of nanotechnology with green processes has achieved great attention in the synthesis of metal and metal oxide nanoparticles, and these nanoparticles show many unique biochemical, physicochemical, and optoelectronic properties. The common metal and metal oxide nanoparticles are silver $(\mathrm{Ag})$, gold $(\mathrm{Au})$, copper $(\mathrm{Cu})$, manganese $(\mathrm{Mn})$, iron $(\mathrm{Fe})$, palladium $(\mathrm{Pd})$, platinum (Pt), cupric oxide $(\mathrm{CuO})$, manganese oxide $\left(\mathrm{MnO}_{2}\right)$, calcium oxide ( $\mathrm{CaO})$, magnesium oxide $(\mathrm{MgO})$, iron oxide $\left(\mathrm{Fe}_{2} \mathrm{O}_{3}\right)$, zinc oxide $(\mathrm{ZnO})$, and titanium oxide $\left(\mathrm{TiO}_{2}\right)$ [1-12]. Researchers have now focused on the developing of green synthetic methods for these nanoparticles because such nanoparticles are used as catalysts, in medical applications, disinfection, as antimicrobials, semiconductors, cosmetics, and chemical sensing devices [13-17]. Cupric oxide nanoparticles (CuONPs) have attracted great attention due to their applications in biomedical, supercapacitors, magnetic storage media, sensors, catalysis, and semiconductors [18-20]. Biologically synthesized CuONPs are safer than chemically originated CuONPs and biomedically become more effective to inhibit the growth of microorganisms [23]. The plant Tulsi (Ocimum tenuiflorum) belongs to Angiospermic family Lamiaceae and has many medicinal properties and used in traditional medicines and pharmaceuticals. In India, this plant is known for worship and grown at temples and homes. Metabolites present in the aerial part of the plant are used in the treatment of diarrhea, bronchitis, dysentery, etc [21-24]. The leaves of 0 . tenuiflorum have been collected from a local garden near Uttaranchal University Dehradun (India).

\section{METHODS}

Preparation of leaves extract

After several washing of collected leaves of 0 . tenuiflorum with double distilled water, leaves were cut into possible small pieces and $2 \mathrm{~g}$ of leaves added with $100 \mathrm{ml}$ of double distilled water. The content was boiled for 30 min on a magnetic stirrer with a constant shake. After boiling, the mixture was cooled down and filtered with Whatman filter paper. The filtrate was used as an extract and preserved at $4^{\circ} \mathrm{C}$ for further uses.

\section{Synthesis and characterizations of CuONPs}

Take a requisite amount of copper acetate $\mathrm{Cu}\left(\mathrm{CH}_{3} \mathrm{COO}\right)_{2}$ in $100 \mathrm{ml}$ of double distilled water to make $0.2 \mathrm{M}$ copper acetate solution. Add $10 \mathrm{ml}$ of leaves extract in this solution and mixed properly with a shake for 25-30 min on a magnetic stirrer. The color change of this solution from blue to green indicated the formation of copper nanoparticles. Now, this solution was continuously stirred for $2.5 \mathrm{~h}$ and then heated at $80^{\circ} \mathrm{C}$ for $3 \mathrm{~min}$ and then added dropwise $0.1 \mathrm{M} \mathrm{NaOH}$ solutions. The formation of brownish-black precipitate indicated the formation of CuONPs. This black precipitate was isolated from the solution by centrifugation at 10,000 rpm for $10 \mathrm{~min}$. Further, precipitate washed with ethanol to remove all impurities and then heated at $60-65^{\circ} \mathrm{C}$ in a hot air oven. The dried CuONPs were preserved in airtight bottles for characterizations and antimicrobial activities. The characterization methods included Fourier transform infrared (FTIR), ultraviolet (UV)visible, X-ray powder diffraction (XRD), and field-emission scanning electron microscopy (FESEM) [21,25].

\section{Antimicrobial activity}

The antibacterial activity of CuONPs against Escherichia coli, Streptococcus mutans, Staphylococcus aureus, and Proteus vulgaris was checked using well diffusion method. The liquid media was poured 
on sterilized Petri plates and then solidified. The nanoparticles were loaded on the wells on the agar plates and then incubated. After the incubation period, the zones of inhibition around the nanoparticles have been measured $[20,25]$

\section{RESULTS}

\section{Characterizations of CuONPs}

\section{UV-visible}

UV-visible spectroscopy is the very economic and common method used to analyze organic, polymeric as well inorganic compounds. Electron transition takes place from lower energy to higher energy levels in the atoms or molecules after absorption of the precise wavelength of UV and visible radiations. The UV-visible spectra of CuONPs are represented in Fig. 1 in the range of wavelength $220-400 \mathrm{~nm}$.

\section{FTIR}

FTIR spectroscopy is used to observe the presence of bonds on the surface of biologically originated nanomaterials. This technique is very useful in the study of a variety of quantitative analysis and bonding mechanisms on the surface of solids. It is also very economical, sensitive, and nondestructive interference-based technique [26,27]. The FTIR spectra of CuONPs is shown in Fig. 2 in the range between 4000 and $500 \mathrm{~cm}^{-1}$.

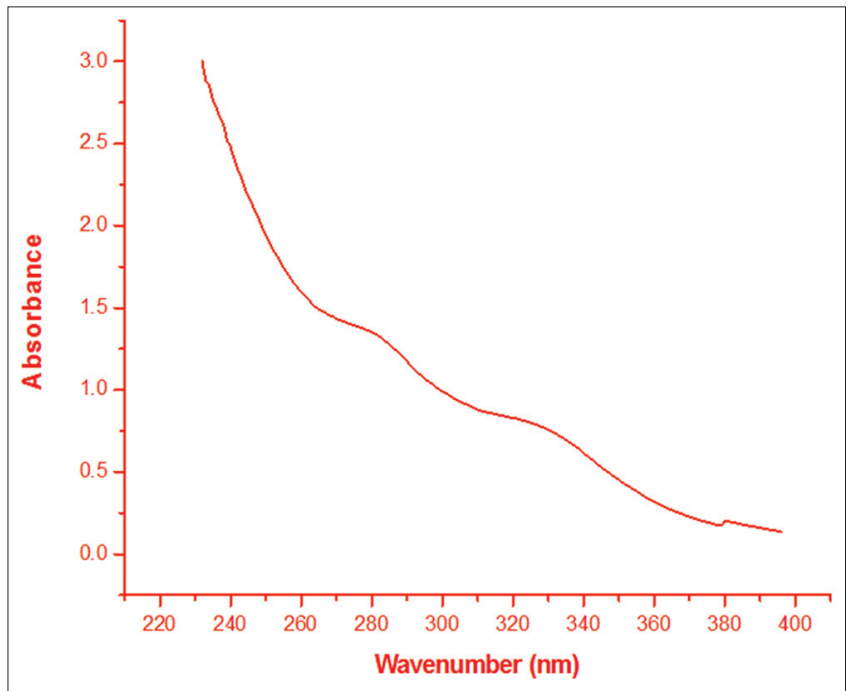

Fig. 1: Ultraviolet-visible spectra of cupric oxide nanoparticles

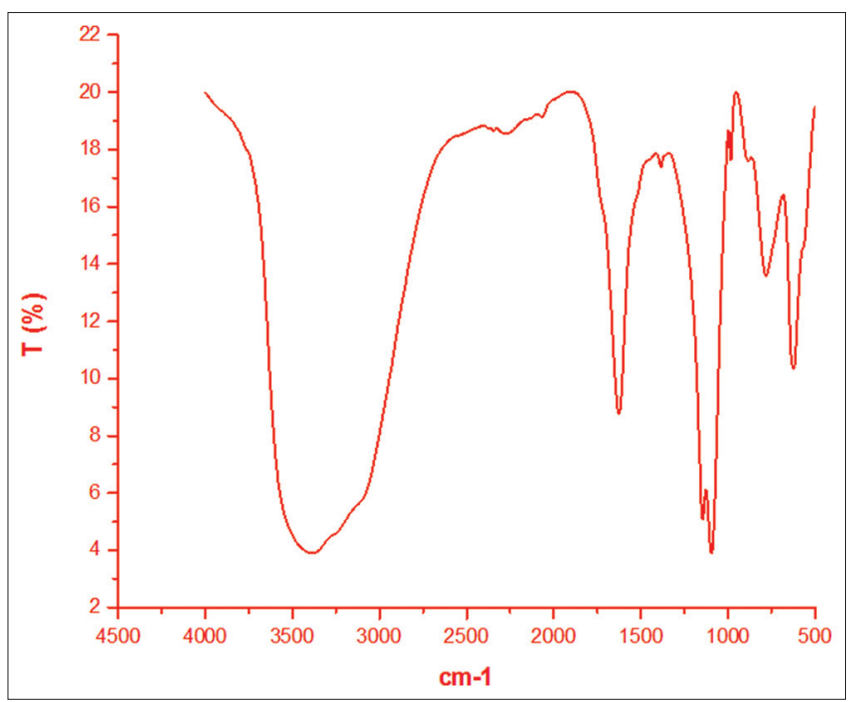

Fig. 2: Fourier transform infrared spectra of cupric oxide nanoparticles
Powder XRD

XRD is an advanced analytical technique used for the analysis of finely ground and homogenized materials. It provides phase identifications, unit cell dimensions, and determines the average bulk compositions. The scattered X-rays from particles produce a diffraction pattern and which finally provides an atomic arrangement in crystals [28-30]. The XRD pattern of CuONPs is represented in Fig. 3.

\section{FESEM}

FESEM is based on the scanning of nanoparticles with high-energy electrons under higher vacuum conditions. It provides the morphological characteristics of nanoparticles, and the FESEM images of CuONPs are shown in Fig. 4; the agglomerated CuONPs show spherical as well as thick-needle morphologies.

\section{Antimicrobial activity}

Most of metal and metal oxide nanoparticles have now been identified as good antimicrobial agents. Due to their small size and effectiveness, they show efficient inhibition mechanisms inside the cell of microorganisms. Biologically synthesized nanomaterials are more efficient and unique than chemically originated nanomaterials. Biogenic CuONPs are one of them and very effective to destroy bacterial cells; the antibacterial activity of CuONPs has been checked by using well diffusion method against S. mutans, E. coli, S. aureus, and P. vulgaris. The CuONPs were loaded on the wells on the agar plate and after the incubation period, significant zones of inhibition found around the loaded nanoparticles.

\section{DISCUSSION}

In UV-visible spectra, the elevated peaks are obtained at 285 and $330 \mathrm{~nm}$ indicate the formation of CuONPs using Tulsi leaves extract at such

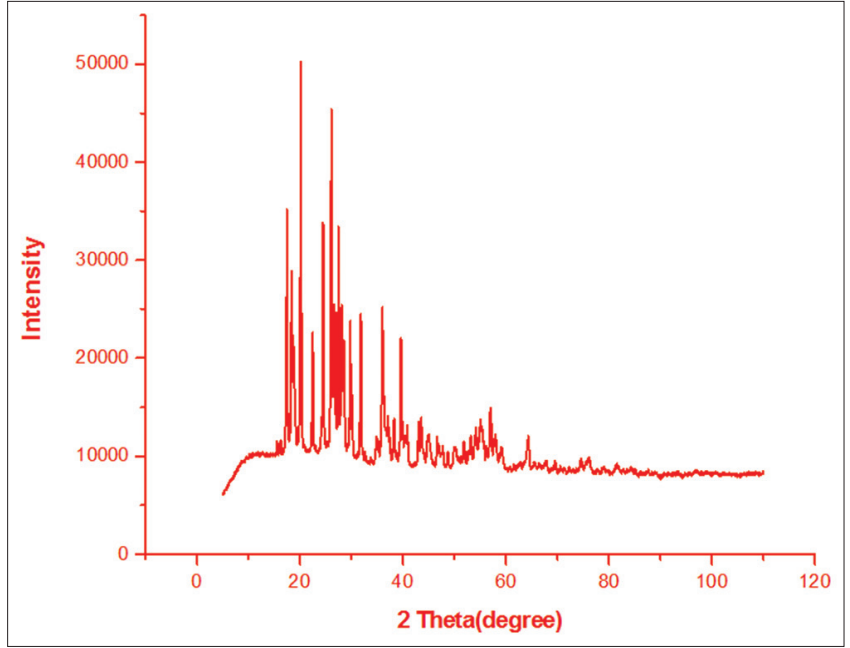

Fig. 3: X-ray powder diffraction patterns of cupric oxide nanoparticles
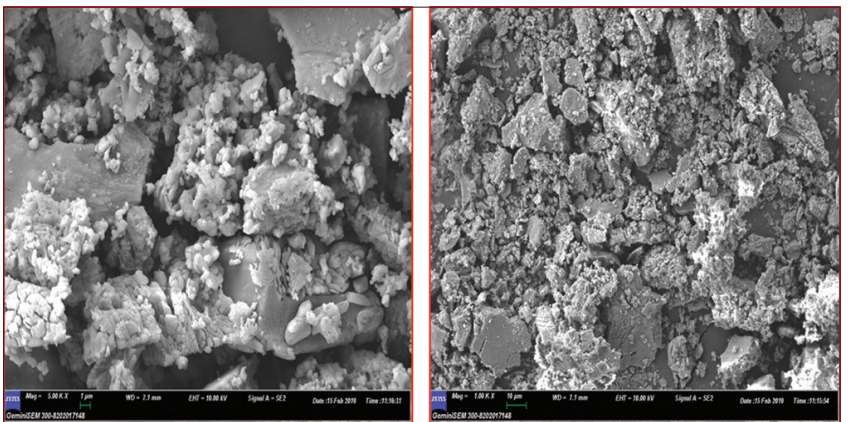

Fig. 4: FESEM images of cupric oxide nanoparticles 
wavelengths. Broad peaks of FTIR are found at $3392 \mathrm{~cm}^{-1}, 1625 \mathrm{~cm}^{-1}$, $1384 \mathrm{~cm}^{-1}, 1144 \mathrm{~cm}^{-1}, 1094 \mathrm{~cm}^{-1}, 982 \mathrm{~cm}^{-1}, 780 \mathrm{~cm}^{-1}$, and $621 \mathrm{~cm}^{-1}$. These peaks indicate the presence of $\mathrm{O}-\mathrm{H}, \mathrm{N}-\mathrm{H}, \mathrm{C}=\mathrm{O}, \mathrm{C}-\mathrm{O}, \mathrm{C}-\mathrm{C}, \mathrm{Cu}-\mathrm{O}$, $\mathrm{Cu}-\mathrm{C}$, etc., bonds on the surface of biologically synthesized CuONPs. The XRD peaks are assigned at $32.6^{\circ} 0,38.6^{\circ}, 48.9^{\circ}, 53.4^{\circ}, 58.2^{\circ}, 61.8^{\circ}$, $66.2^{\circ}, 68.2^{\circ}$, and $76.2^{\circ}$. These peaks are corresponding to 110,111 , $202,020,202,113,022,220$, and 311 planes, respectively [18,21]. The CuONPs enter into the bacterial cells which cause distortions and destroy the cell membranes and that finally cause death a bacterial cell $[1,9,15,18,31,32]$. At initial dosage $5 \mathrm{mg} / \mathrm{ml}$ of CuONPs, the zones of inhibitions have been observed $18 \mathrm{~mm}, 12 \mathrm{~mm}, 14 \mathrm{~mm}$, and $16 \mathrm{~mm}$ for S. mutans, S. aureus, E. coli, and P. vulgaris. The zones of inhibition were increased with increase in the amount of CuONPs on the agar plates and maximum zones of inhibition recorded $38 \mathrm{~mm}, 34 \mathrm{~mm}, 32 \mathrm{~mm}$, and $28 \mathrm{~mm}$ for S. mutans, S. aureus, E. coli, and P. vulgaris $15 \mathrm{mg} / \mathrm{ml}$ of CuONPs (Table 1, Fig. 5).

\section{CONCLUSIONS}

The biological-based nanomaterials are specific and have more potential and with some advanced properties than chemically synthesized nanobased materials. In this study, we have observed the applied green synthetic method which is more efficient and suitable to synthesize CuONPs. These nanoparticles have been well analyzed by FTIR,

Table 1: Effect of dosage of CuONPs on bacterial species

\begin{tabular}{lll}
\hline Bacterial species & $\begin{array}{l}\text { Amount of CuONPs } \\
\text { (mg/ml) }\end{array}$ & $\begin{array}{l}\text { Zones of inhibition } \\
\text { (mm) }\end{array}$ \\
\hline S. mutans & 5 & 18 \\
S. aureus & 5 & 12 \\
E. coli & 5 & 14 \\
P. vulgaris & 5 & 16 \\
S. mutans & 7.5 & 26 \\
S. aureus & 7.5 & 18 \\
E. coli & 7.5 & 16 \\
P. vulgaris & 7.5 & 18 \\
S. mutans & 10 & 30 \\
S. aureus & 10 & 24 \\
E. coli & 10 & 22 \\
P. vulgaris & 10 & 18 \\
S. mutans & 12.5 & 36 \\
S. aureus & 12.5 & 28 \\
E. coli & 12.5 & 26 \\
P. vulgaris & 12.5 & 24 \\
S. mutans & 15 & 38 \\
S. aureus & 15 & 34 \\
E. coli & 15 & 32 \\
P. vulgaris & 15 & 28 \\
\hline
\end{tabular}

E. coli: Escherichia coli, S. mutans: Streptococcus mutans, P. vulgaris: Proteus vulgaris, S. aureus: Staphylococcus aureus

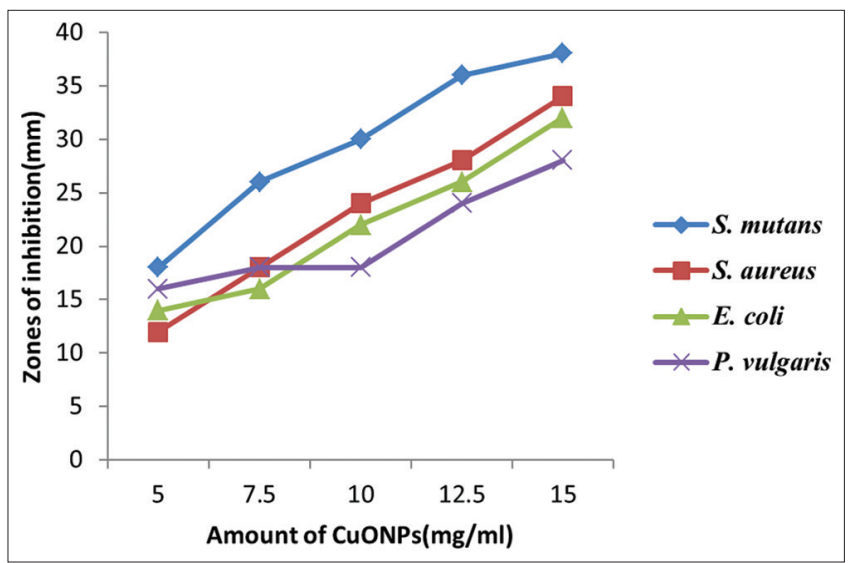

Fig. 5: Zones of inhibition with amount of cupric oxide nanoparticles
UV-visible, FESEM, and XRD and found a good antibacterial agent for $S$. mutans, S. aureus, E. coli, and P. vulgaris under our laboratory scales.

\section{ACKNOWLEDGMENT}

We are very thankful to the Department of chemistry, Uttaranchal University Dehradun (India) for providing the all necessary facilities during the experimental works.

\section{AUTHORS' CONTRIBUTIONS}

The experimental work was carried out by Mrs. Yashwani Prakash under the supervision of Dr. Naveen Chandra Joshi in Advanced chemistry laboratory, Uttaranchal University, Dehradun (India). The characterizations of CuONPs and writing work have been completed by Dr. Naveen Chandra Joshi.

\section{CONFLICT OF INTEREST}

The authors declare that they have no conflict of interest

\section{REFERENCES}

1. Joshi NC, Chhabra J. Biological synthesis of silver nanoparticles using the tuberous root extract of Ipomoea batatas and their characterisations and antibacterial activity. Asian J Pharm Clin Res 2019;12:300-3.

2. Joshi NC, Kumar V, Singh A. A brief discussion on the green synthesis and characterisation of copper nanoparticles (CuNPs). Int J Res Advent Tech 2019;7:201-4.

3. Thakkar KN, Mhatre SS, Parikh RY. Biological synthesis of metallic nanoparticles. Nanomedicine 2010;6:257-62.

4. Patil SR, Sivaraj P, Rajiv R, Venckatesh R, Seenivasan R. Green synthesis of silver nanoparticle from leaf extract of Aegle marmelos and evaluation of its antibacterial activity. Int J Pharm Pharm Sci 2015;7:169-73.

5. Raj LF, Jayalakshmy E. A biogenic approach for the synthesis and characterization of zinc oxide nanoparticles produced by Tinospora cordifolia. Int J Pharm Pharm Sci 2015;8:384-6.

6. Menon S, Agarwal H, Kumar SR, Kumar SV. Green synthesis of silver nanoparticles using medicinal plant Acalypha indica leaf extracts and its application as an antioxidant and antimicrobial agent against foodborne pathogens. Int J Appl Pharm 2017;9:42-50.

7. Anbarasu A, Karnan P, Deepa N, Usha R. Carica papaya mediated green synthesized silver nanoparticles. Int J Curr Pharm Res 2018;10:15-20.

8. Calle LC, Lopez ME. Green synthesis of silver nanoparticles using green coffee bean extract. In: Torres I, Bustamante J, Sierra D, editors. VII Latin American Congress on Biomedical Engineering CLAIB 2016, Bucaramanga, Santander, Colombia, IFMBE Proceedings. Singapore: Springer; 2017. p. 60.

9. Siddiqi KS, Husen A, Rao RAK. A review on biosynthesis of silver nanoparticles and their biocidal properties. J Nanobiotechnology 2018;16:14.

10. Das SK, Khan MM, Guha AK, Das AR, Mandal AB. Silvernanobiohybride material: Synthesis,characterizationand application in water purification. Bioresour Technol 2012;124:495-9.

11. Das SK, Dickinson C, Lafir F, Brougham DF, Marsili E. Synthesis, characterization and catalytic activity of goldnanoparticles biosynthesized with Rhizopus oryzae protein extract. Green Chem 2012; $14: 1322-34$.

12. Das SK, Khan MM, Guhab AK, Naskar N. Bio-inspired fabrication of silver nanoparticles on nanostructured silica: Characterization and application as a highly efficient hydrogenationcatalyst. Green Chem 2013; $15: 2548-57$

13. Sahooli M, Sabbaghi S, Saboori R. Synthesis and characterization of mono sized $\mathrm{CuO}$ nanoparticles. Mater Lett 2012;81:169-72.

14. Khashan KS, Sulaiman GM, Abdulameer FA. Synthesis and antibacterial activity of $\mathrm{CuO}$ nanoparticles suspension induced by laser ablation in liquid. Arab J Sci Eng 2016;41:301-10.

15. Katwal R, Kaur H, Sharma G, Naushad M, Pathania D. Electrochemical synthesized copper oxide nanoparticles for enhanced photocatalytic and antimicrobial activity. J Ind Eng Chem 2015;31:173-84.

16. Ahamed M, Siddiqui MA, Akhtar MJ, Ahmad I, Pant AB, Alhadlaq HA, et al. Genotoxic potential of copper oxide nanoparticles in human lung epithelial cells. Biochem Biophys Res Commun 2010;396:578-83.

17. Mortimer M, Kasemets K, Kahru A. Toxicity of znO and cuO nanoparticles to ciliated protozoa Tetrahymena thermophila. Toxicology 
2010;269:182-9

18. Baek YW, An YJ. Microbial toxicity of metal oxide nanoparticles $(\mathrm{CuO}, \mathrm{niO}, \mathrm{znO}$, and sb2O3) to Escherichia coli, bacillus subtilis, and Streptococcus aureus. Sci Total Environ 2011;409:1603-8.

19. Isani G, Falcioni ML, Barucca G, Sekar D, Andreani G, Carpenè E, et al. Comparative toxicity of cuO nanoparticles and cuSO4 in rainbow trout. Ecotoxicol Environ Saf 2013;97:40-6.

20. Ostaszewska T, Chojnacki M, Kamaszewski M, Sawosz-Chwalibóg E. Histopathological effects of silver and copper nanoparticles on the epidermis, gills, and liver of siberian sturgeon. Environ Sci Pollut Res Int 2016;23:1621-33.

21. Singh J, Dutta T, Kim KH, Rawat M, Samddar P, Kumar P, et al. Green synthesis of metals and their oxide nanoparticles: Applications for environmental remediation. J Nanobiotechnology 2018;16:84.

22. Khare CP. Indian Medicinal Plants: An Illustrated Dictionary. Berlin: Springer Science and Business Media; 2007.

23. Prakash P, Gupta N. Therapeutic uses of Ocimum sanctum Linn (Tulsi) with a note on eugenol and its pharmacological actions: A short review. Indian J Physiol Pharmacol 2005;49:125-31.

24. Rao PS, Satelli A, Moridani M, Jenkins M, Rao US. Luteolin induces apoptosis in multidrug resistant cancer cells without affecting the drug transporter function: Involvement of cell line-specific apoptotic mechanisms. Int J Cancer 2012;130:2703-14

25. Murthy HC, Abebe B, Prakash CH, Shantaveerayya K. A review on green synthesis of $\mathrm{Cu}$ and $\mathrm{Cuo}$ nanomaterials for multifunctional applications. Mat Sci Res India 2018;15:279-95.

26. Joshi NC, Singh A, Rajput H. Utilization of waste leaves biomass of Myrica esculenta for the removal of $\mathrm{Pb}(\mathrm{II}), \mathrm{Cd}(\mathrm{II})$ and $\mathrm{Zn}$ (II) ions from waste waters. Orient J Chem 2018;34:2548-53.

27. Joshi NC, Rangar V, Sati R, Joshi E, Singh A. Adsorption behavior of waste leaves of Quercus leucotrichophora for the removal of $\mathrm{Ni}^{2+}$ and $\mathrm{Cd}^{2+}$ ions from waste water. Orient J Chem 2018;35:591-6.

28. Joshi NC, Chodhary A, Prakash Y, Singh A. Green synthesis and characterization of $\alpha-\mathrm{Fe} 2 \mathrm{O} 3$ nanoparticles using leaf extract of syzygium cumini and their suitability for adsorption of $\mathrm{Cu}(\mathrm{II})$ and $\mathrm{Pb}(\mathrm{II})$ ions. Asian J Chem 2019;31:1809-14.

29. Ramola B, Joshi NC, Ramola M, Chhabra J, Singh A. Green synthesis, characterisations and antimicrobial activities of $\mathrm{CaO}$ nanoparticles. Orient J Chem 2019;35:1154-7.

30. Skoog DA, Holler FJ, Crouch SR. Principles of Instrumental Analysis. $6^{\text {th }}$ ed. United States: Thomson Brooks; 2007.

31. Salas-Orozco M, Niño-Martínez N, Martínez-Castañón GA, Méndez FT, Eugenia M, Jasso C, et al. Mechanisms of resistance to silver nanoparticles in endodontic bacteria: A literature review. J Nanomater 2019;2019:11.

32. Wypij M, Czarnecka J, Świecimska M, Dahm H, Rai M, Golinska P, et al. Synthesis, characterization and evaluation of antimicrobial and cytotoxic activities of biogenic silver nanoparticles synthesized from Streptomyces xinghaiensis OF1 strain. World J Microbiol Biotechnol 2018;34:23. 